\title{
LIVE-CAPTURES OF COMMON BOTTLENOSE DOLPHINS TURSIOPS TRUNCATUS AND UNASSESSED BYCATCH IN CUBAN WATERS: EVIDENCE OF SUSTAINABILITY FOUND WANTING
}

\author{
Koen Van Waerebeek ${ }^{1}$ *, Marina Sequeira ${ }^{2}$, Cathy Williamson ${ }^{3}$, \\ Gian Paulo Sanino ${ }^{4}$, Pierre Gallego ${ }^{5}$ and Paulo Carmo ${ }^{2}$
}

\begin{abstract}
AвsтRAct: In the period 1986-2004, 238 common bottlenose dolphins Tursiops truncatus were exported from Cuba, as shown by UNEP/WCMC data, more than $60 \%$ of these to facilities in Latin America and the Caribbean, some $32 \%$ to Europe and the rest to Canada and Israel. There is a very significant increase in exported numbers, reaching 28 individuals per annum in 2002. It is unclear how many T. truncatus have been used in domestic dolphinaria. A review of available information did not identify evidence to corroborate hypotheses that: (i) T. truncatus off Sabana-Camagüey Archipelago (where removals occur) does not show population structure; and (ii) virtually no bycatches occur in Cuban waters. Here it is argued that, considering Cuba's fully developed marine fisheries, some level of mortality from bycatch is inevitable. Other potential threats are also identified. Global phylogenetics research of T. truncatus is revealing unexpected and more complex, stock structures, in inshore (coastal) forms within relatively small areas. In Cuba, low mean group sizes (less than 10) suggest that one or more coastal stock(s) are exploited. Sex distribution of measured specimens suggest a significant bias towards extraction of females. It is concluded that sustainability of harvest levels of Cuban T. truncatus cannot be evaluated until abundance estimates become available and population structure is verified by molecular genetic methods. Pérez-Cao (2004) indicated that available density estimates should not be used to determine [safe] catch quotas. The authors strongly recommend that international trade of T. truncatus from Cuba ceases until no-detriment can be authenticated and that more research be developed. Similar arguments may be applicable to other unassessed but exploited populations in the Wider Caribbean.
\end{abstract}

RESUMEn: En el período 1986-2004, según datos obtenidos de PNUMA/WCMC, 238 delfines mular común Tursiops truncatus fueron exportados de Cuba; más del 60\% de éstos hacia acuarios en América Latina y el Caribe, unos 32\% a Europa y el resto hacia Canadá e Israel. Se distingue un aumento muy significativo en los números exportados, hasta 28 individuos per annum (en 2002). No hay información sobre el número de T. truncatus usados en acuarios domésticos en Cuba. Tras una revisión de la información disponible, no se encontraron evidencias para corroborar las hipótesis sugeridas que: (i) T. truncatus en el Archipiélago de Sabana-Camagüey (donde ocurre la explotación) no se presenta estructura de población y (ii) que virtualmente no ocurre ninguna captura accidental. Argumentamos que, considerando una pesquería marina plenamente desarrollada en Cuba, es inevitable algún nivel de capturas accidentales, y se identifica otras posibles amenazas. La investigación filogenética en T. truncatus, a nivel global, revela inesperada estructura o estructuras de stocks más complejas en la forma costera. Grupos de menor tamaño (menos de 10 indivíduos) sugieren que uno (o más) stocks costeros son explotados en Cuba. Distribución de frecuencia de sexos sugiere un sesgo significativo hacia las hembras. Mientras que no estén disponibles estimaciones de abundancia (absoluta) al igual que información sobre estructura genética de poblaciones, no se puede evaluar la sostenibilidad de la extracción actual en Cuba. Pérez-Cao (2004) tambien indicó que las estimaciones de densidad relativa no permiten determinar cuotas de captura. Los autores recomiendan que el comercio internacional de T. truncatus desde Cuba cese hasta que se demuestre el no detrimento, además que se desarollen estudios adicionales. Argumentos similares pueden aplicarse a otras poblaciones explotadas pero no evaluadas en el Caribe.

KEYWORDS: common bottlenose dolphin, live-capture fishery, bycatch, international trade, sustainability, Cuba, Wider Caribbean.

\section{Introduction}

Atlantic common bottlenose dolphins Tursiops truncatus (Montagu, 1821) have been the target of a direct livecapture fishery off Cuba's coasts since at least 1982. It is the largest and longest running such fishery in the Caribbean region and provides new animals to the global captive dolphin industry, especially in Europe, Latin America and the Caribbean. Except in a few areas, the global demand for live-caught bottlenose dolphins remains as strong as ever and has, in fact, increased in recent decades (Fisher and Reeves, 2005). Even in North American facilities, after half a century of building a remarkable expertise in husbandry with satisfactory survival rates, as of 1996, captive-born bottlenose dolphins still constituted only $44 \%$ of the total number in captivity (Corkeron, 2002; Fisher and Reeves, 2005). None have been live-captured in the USA since 1988-89 (Randall Wells, pers. communication to KVW).

In terms of population dynamics and conservation, live-captures are equivalent to lethal removals: captured individuals are no longer available for recruitment within the wild population. The conventional view in wildlife management theory states that impact is strongest if mostly young animals and reproductive females are removed. The rationale

\footnotetext{
${ }^{1}$ Peruvian Centre for Cetacean Research (CEPEC), Museo de Delfines, Pucusana, Peru.

2 Instituto da Conservação da Natureza, Rua de Santa Marta 55, 1150-294 Lisboa, Portugal.

${ }^{3}$ Whale and Dolphin Conservation Society, Brookfield House, 38 St. Paul Street, Chippenham SN15 ILJ, United Kingdom.

${ }^{4}$ Centre for Marine Mammals Research Leviathan, Santiago, Chile.

${ }^{5}$ National Museum of Natural History, G-D of Luxembourg; and Ministry of the Environment, G-D of Luxembourg.

* Corresponding author: museodedelfines@speedy.com.pe.
} 
for male-selective harvest of mammals is founded in the understanding that (for polygynous or promiscuous species), so long there are enough males to mate available females, it is the female component that determines population growth (Caughley, 1977; McLoughlin et al., 2005). No quantitative modelling of cohort-selective harvest specifically addresses $T$. truncatus, and older animals may also be valuable to the dolphin population if learned behaviour and cultural transmission (see e.g. Rendell and Whitehead, 2001) would significantly contribute to survival fitness. Nonetheless, it seems unlikely that such a factor could match, in effect, the overriding importance of young, reproductive females.

The IUCN Cetacean Specialist Group (CSG) has long emphasized the need for an appropriate status assessment and independent scientific review before proceeding with takes of cetaceans. Reeves et al. (2003) state specifically: 'As a general principle, dolphins should not be captured or removed from a wild population unless that specific population has been assessed and it has been determined that a certain amount of culling can be allowed without reducing the population's long-term viability or compromising its role in the ecosystem. Such an assessment, including delineation of stock boundaries, abundance, reproductive potential, mortality, and status (trend) cannot be achieved quickly or inexpensively, and the results should be reviewed by an independent group of scientists before any captures are made.' The $T$. truncatus listing in CITES Appendix $\mathrm{II}^{6}$ requires the exporting state to provide a non-detriment finding (NDF), i.e. a supporting document that demonstrates 'that such export will not be detrimental to the survival of that species' (CITES, Art.IV, § 2.a).

Import of T. truncatus into European Union member states moreover is subject to EU Council Regulation CE 338/97 for species that are listed in its Annex A. It requires importing EU nations to confirm sustainability of captures ${ }^{7}$ and that the import must be "intended for breeding or propagation purposes from which conservation benefits will accrue to the species concerned; or it is intended for research or education aimed at the preservation or conservation of the species." To the best of our knowledge, none of the common bottlenose dolphins exported from Cuba, or any offspring, have been, or are meant to be, returned to the wild, and conservation benefits are nil. Captive breeding for conservation purposes has often been invoked prematurely and appreciation of its limitations has grown (e.g. Snyder et al.,1996). It should be viewed as a last resort in species recovery and not a prophylactic or long-term solution because of the inexonerable genetic and phenotypic changes that occur in captive environments (Snyder et al.,1996).

There are a few other international conventions with overlapping regulatory framework for responsible management of living marine resources, all with the purpose to ensure long-term sustainability. The Cartagena Convention (Convention for the Protection and Development of the Marine Environment of the Wider Caribbean Region), under its SPAW Protocol (Specially Protected Areas and Wildlife in the Wider Caribbean Region) has placed cetaceans on its Annex II. This requires that each Party "ensure total protection and recovery to the species of fauna listed in Annex II by prohibiting the taking, possession or killing (including, to the extent possible, the incidental taking, possession or killing) or commercial trade in such species, their eggs, parts or products." Cuba ratified the SPAW Protocol on 11 September 2003. In this paper we critically examine the exploitation of T. truncatus in Cuban waters for evidence of sustainability $^{8}$

\section{Material and Methods}

Numbers of T. truncatus exported annually from Cuba were compiled (Table 1) and checked with import data for importing countries, based on records from the United Nations Environment Programme's World Conservation Monitoring Centre (UNEP/WCMC). Presumably all specimens originated from Cuban waters, more specifically from the western SabanaCamagüey Archipelago (Pérez-Cao, 2004). The number of bottlenose dolphins taken for use in Cuban dolphinaria and pools where people pay for the opportunity to swim with dolphins, so-called 'swimwith programmes' (e.g. Acuario Nacional de Cuba, Varadero, Holguin) is unreported, but may be substantial. Also unknown is the extent to which traumatic injuries or deaths of dolphins have occurred during, or immediately after, the capture operations, although it was hinted that there were none (Anon., 2003).

The literature was searched comprehensively but merely five pertinent documents were found that discuss aspects of the status of T. truncatus in Cuba, only one of which was published in a peer-reviewed

\footnotetext{
${ }^{6}$ CITES (2006) Convention on International Trade in Endangered Species of Wild Fauna and Flora. Official web site. Appendices I, II, III. http://www.cites.org/eng/app/appendices.shtml.

${ }^{7}$ The import by a EU member state of species listed in Annex A will only be authorized if the capture 'will not have a harmful effect on the conservation status of the species or on the extent of the territory occupied by the relevant population of the species.'

${ }^{8}$ An early draft of this paper (SC/58/SM26) was presented to the Small Cetacean Sub-Committee of the International Whaling Commission, St.Kitts \& Nevis, May-June 2006.
} 
journal (Aguayo, 1954), two conference abstracts (Cortez-Aguilar et al., 20009; Pérez-Cao et al., 2001 ${ }^{10}$ ), a master's dissertation (Pérez-Cao, 2004) and an unpublished report SRG28 Inf7' (Anon., 2003). The latter report was made available to the EU Scientific Review Group (SRG) dealing with CITES issues and international trade in wildlife, in lieu of a non-detriment finding, to justify the import of live common bottlenose dolphins into Spain and Portugal. Pérez-Cao (2004) cited two other unpublished documents, which could not be obtained, but they were prior to her dissertation.

Here we examine whether sufficient biological and management information is available, including that presented in Anon. (2003), to allow independent scientists (sensu CSG/IUCN, Reeves et al., 2003) to determine whether current removals of Cuban T. truncatus could have a harmful effect on the wild population(s).

Although adequate husbandry is also a requisite in regulatory legislation pertaining to international trade in live cetaceans, including CITES, we do not analyse this aspect. This must however not be interpreted that the imports discussed here were void of husbandry infractions, in fact some contributed to major changes in national management policy. For instance, of two dolphins exported to Chile for a travelling exhibition in 1995, one died and the abandoned second dolphin was returned, ailing, to Cuba for release but also died in custody. The public outcry that ensued urged the Chilean government to effectively freeze and, in 2005, ban all trade in live cetaceans ${ }^{11}$.

Table 1. International trade of 238 common bottlenose dolphins Tursiops truncatus exported from Cuba between 1986 and 2004 (UNEP/WCMC data).

\begin{tabular}{lrll}
\hline \hline YEAR & TOTAL NO. & \multicolumn{1}{c}{ IMPORTING COUNTRIES (NO. OF INDIVIDUALS, PURPOSE) } \\
\hline \hline 1986 & 8 & Canada (8,Z) \\
\hline 1987 & 3 & Italy (3,E) \\
\hline 1988 & 11 & Spain (1,Z), France (6,Z), Italy (4,E) \\
\hline 1989 & 2 & Italy (2,E) \\
\hline 1990 & 12 & Switzerland (6,Z), Spain (6,Z) \\
\hline 1991 & 2 & Switzerland (2,Q) \\
\hline 1993 & 4 & Spain (4,E) \\
\hline 1994 & 11 & Colombia (3,Q), Mexico (8,Z) \\
\hline 1995 & 15 & Chile (2), Spain (6,S), Mexico (7,Q) \\
\hline 1996 & 11 & Argentina (3), Dominican Republic (4,E), Mexico (4,Q+Z) \\
\hline 1997 & 15 & Spain (2,E), Mexico (13,Q+Z) \\
\hline 1998 & 14 & Argentina (2), Mexico (10,Q), Venezuela (2, P) \\
\hline 1999 & 24 & Dominican Republic (2,T), Spain (2,E), Israel (6), Mexico (8,Q), Portugal (6,Z) \\
\hline 2000 & 24 & Anguilla (6), Spain (4,E), Mexico (14,Q+Z) \\
\hline 2001 & 9 & Argentina (1,Z), Spain (2), Mexico (6,Q), \\
\hline 2002 & 28 & Dominican Republic (4,T), Spain (15,E), Mexico (9,Q+B) \\
\hline 2003 & 20 & Malta (6, T), Mexico (10,Q), British Virgin Islands (4) \\
\hline 2004 & 25 & Antigua and Barbuda (3), Jamaica (10,T), Mexico (12,Q+T) \\
\hline \hline
\end{tabular}

Import destinations include Latin America and Caribbean (61.8\%), Europe (32.3\%), Canada (3.4\%) and Israel (2.5\%). Where known, import purposes are Zoos (Z), Circuses and travelling exhibitions (Q), Educational (E), Commercial Trade (T), Scientific (S) and Breeding (B). Of the six dolphins recorded for export to Portugal in 1999, only four entered Portugal; two died in Cuba before being transferred.

\footnotetext{
${ }_{9}^{9}$ Cortez-Aguilar, A. M., Pérez-Cao, H. and Akimova, V. L. (2000) Delfines tonina (Tursiops truncatus) en el Archipiélago SabanaCamaguey, Cuba: primera aproximación. XXV Reunión Internacional para el Estudio de los Mamíferos Marinos, La Paz, B.C.S., México 7-11 de mayo 2000. [in Spanish]

${ }^{10}$ Pérez-Cao, H., Cortez-Aguilar, A. M. and Akimova, V. L. (2001) Zonas de mayor probabilidad de avistamientos de delfines tonina (Tursiops truncatus) en areas aledañas a Cayo Coco, en el archipielago Sabana-Camaguey, Cuba. XXVI Reunión Internacional para el Estudio de los Mamíferos Marinos. Ensenada, B.C., México, 6-10 mayo 2001. [in Spanish]

${ }^{11}$ Ministerio de Economía, Fomento y Reconstrucción, Santiago, Chile: Decreto Exento No 135 del 18 de enero de 2005, modifying Decreto No225 of 1995.
} 


\section{Summary of international trade}

\section{Trading countries}

WCMC data report the export of 238 bottlenose dolphins from Cuba between 1986 and 2004. Eighteen countries are recorded as having imported dolphins from Cuba: Anguilla, Antigua and Barbuda, Argentina, British Virgin Islands, Canada, Chile, Colombia, Dominican Republic, France, Israel, Italy, Jamaica, Malta, Mexico, Portugal, Spain, Switzerland and Venezuela.

\section{Indicated sources and purposes of traded animals}

Of 48 separate events of import or export, covering the 238 bottlenose dolphins, the source of the animals is reported as 'wild' in $40(83.3 \%)$ cases, while it is not given in eight cases. However, probably all dolphins were wildcaught. Seven different purposes of import were reported: 'Zoos' in 11 cases (covering 23.9\% of animals), 'Educational' in 9 imports $(16.8 \%)$, 'Circuses and travelling exhibitions' in 12 (29.8\%), 'Commercial trade' in five $(12.6 \%)$, and each 'Scientific' $(2.5 \%)$, 'Breeding in captivity' $(1.7 \%)$ and 'Personal' $(0.8 \%)$ in one case.

Discrepancies existed between reported import and export purposes in three cases. In the 1997 and 1999 events of export to Spain, the purpose of export was recorded as 'Commercial trade', while recorded purpose of import was 'Educational'. In a 1999 export to Portugal, the recorded purpose of import 'Zoos' differed from the purpose of export 'Commercial trade'.

Similar reporting problems in the global trade of cetaceans were also pointed out by Fisher and Reeves (2005). As discrepancies demonstrate, the usefulness of non-standardized entries for 'purpose of trade' is debatable. Moreover, with the possible exception of the (single) 'Scientific' entry, all bottlenose dolphins were destined for display in primarily commercial entreprises. Whatever other uses these dolphins may or may not have, the dynamics of this trade, without doubt, are pecuniary driven.

\section{Status of common bottlenose dolphins in Cuba}

\section{Distribution and population structure}

T. truncatus is a highly polymorphic species at both large and small geographic scales, and the existence of distinct geographic races, distinguishable by morphology, molecular genetics and ecological markers, are well documented (e.g. Hersh and Duffield, 1990; Van Waerebeek et al., 1990; Mead and Potter, 1995; LeDuc and Curry, 1997; Hoelzel et al., 1998; Rice, 1998; Wang et al., 1999; Wells and Scott, 1999, 2004; Sanino et al., 2005; K.M. Parsons et al., 2006). In the temperate NW Atlantic, coastal (inshore) and offshore forms of $T$. truncatus have fixed genetic differences and eventually may be assigned to different species (Curry and Smith 1997; LeDuc and Curry, 1997; Hoelzel et al., 1998).

The common bottlenose dolphin is the most frequently encountered cetacean in the Gulf of Mexico, much of the Caribbean Sea and contiguous tropical Atlantic waters (e.g. Erdman, 1970; Schmidly, 1981; Jefferson and Lynn, 1994; Blaylock et al., 1995; Mignucci-Giannoni, 1998, 1999; Waring et al., 2005). Still, relatively little is published concerning its distribution around the Greater Antilles, with the exception of Puerto Rico (Erdman, 1970; Erdman et al., 1973; Mignucci-Giannoni, 1998, 1999; Roden and Mullin, 2000). The species was first reported from Cuba half a century ago (Aguayo, 1954) and little was added until the recent dissertation by Pérez-Cao (2004) who studied its distribution and (relative) abundance in two areas of the Sabana-Camagüey Archipelago in northern Cuba. Population structure of T. truncatus off Cuba and in much of the Wider Caribbean remains on the whole undocumented (see Wells and Scott, 1999; Romero et al., 2001). Waring et al. (2005) pointed out that the range of the Northern Gulf of Mexico continental shelf stock may extend into Mexican and Cuban territorial waters; however, 'there are no estimates available of either abundance or mortality from those countries'.

Pérez-Cao (2004) and Cortez-Aguilar et al. (2000) ${ }^{10}$ suggested that possibly no population structure exists in the Sabana-Camagüey Archipelago. Pérez-Cao (2004) based this hypothesis on the low level of re-sightings (two) on a total, for both areas, of 92 photo-identified individuals. However, each area was surveyed only six times over a one-year period. Pérez-Cao hypothesized that T. truncatus in Sabana-Camagüey are exclusively transients, and may form part of one big panmictic population, with some nucleus in more productive zones. While such a scenario is surely possible, an alternative situation where several transient and/or wide-ranging semi-resident populations, with an aggregate abundance of several hundreds of animals, temporarily (seasonally?) occupy varying parts of the $463 \mathrm{~km}$ wide Archipelago would not be incompatible with results and could hardly be excluded.

For instance, Pérez-Cao's (2004: Fig. 22) frequency distribution histogram for group size around Matanzas appeared bimodal, with one subset from the inshore Bahía de Cárdenas and Cinco Leguas areas ranging 110 animals/group, and another (three sightings) from the northern, exposed, ocean front, ranging 25-30 animals/group. Pérez-Cao attributed this to different foraging strategies, which is highly likely, but concurrently this difference would also be congruent with a hypothesis of segregated communities and stocks. A longer-term photo-identification effort would be welcome and molecular genetic studies indispensable. Indeed, in well-researched areas of the northwest Atlantic, findings of marked population structure and substructure in relatively small areas have been the norm. Two morphological stocks, equivalent to an offshore and a coastal ecotype, were named for Great Abaco, Bahamas (Macleod et al., 2004). Further, microsatellite and mtDNA sequence variation 
among coastal bottlenose dolphins from three areas separated by less than $250 \mathrm{~km}$ on Little Bahama Bank, northern Bahamas, revealed a significant degree of subdivision (K.M. Parsons et al., 2006), results which corroborate site fidelity documented through long-term photo-identification studies. Parsons et al. (2006) highlighted the need to consider independent subpopulation units for the conservation of coastal bottlenose dolphins in the Bahamas. McLellan et al. (2002) had argued before that inshore bottlenose dolphins off the USA Atlantic coast probably do not form a single discrete stock, confirming earlier findings by Mead and Potter (1995). A high degree of long-term site fidelity and population structuring has been documented over the past 36 years along the central west coast of Florida, including bays, sounds, estuaries, and adjacent Gulf of Mexico coastal waters, based on behavioural and genetic studies (Irvine et al., 1981; Wells et al., 1987; Scott et al., 1990; Duffield and Wells, 1991; Wells, 1991, 2003; Sellas et al. 2005).

\section{Abundance}

In terms of relative abundance, T. truncatus is reported as the most frequently encountered cetacean species shoreward of the continental shelf edge in much of the Caribbean and the Gulf of Mexico (Erdman, 1970; Schmidly, 1981; Jefferson and Lynn, 1994; MignucciGiannoni, 1998; Kerr et al., 2005) and the second most frequently seen off the Leeward Dutch Antilles (Debrot et al., 1998). In deeper waters, the species is less commonly encountered but mean group size is higher (e.g. Roden and Mullin, 2000). However, except for U.S. Atlantic and Gulf of Mexico waters (e.g. Blaylock et al., 1995; Waring et al., 2005) no absolute abundance estimates exist for the tropical northwestern Atlantic, and none seem to be available for Cuba. Pérez-Cao (2004) studied the relative abundance and distribution of common bottlenose dolphins in Sabana-Camaguey Archipelago, more specifically in waters adjacent to Cayo Coco and northern Matanzas. Study effort consisted of 12 small boat surveys, six in each area, for a total of 2,007.8 nmiles and $322 \mathrm{~h} 79 \mathrm{~min}$ duration. In the Cayo Coco area she reported 27 sightings for a total of 109 individuals (32 of which photo-identified) and an estimated density of 0.14 dolphins / $\mathrm{km}^{2}$. In the Matanzas area, PérezCao (2004) recorded 34 sightings for a total of 253 dolphins (60 of which photo-identified) and estimated a density of 1.28 dolphins $/ \mathrm{km}^{2}$. These results were summarized by Anon. (2003), albeit somewhat unclearly.

The most common behaviours observed were travelling and feeding in Cayo Coco and northern Matanzas respectively. In some sub-areas either no (Bahía de Jigüey), or very few (eastern Bahía de Perros), bottlenose dolphins were encountered, suggesting unsuitable habitat. Local fishermen had not seen dolphins in Bahía Jigüey for years. Possibly the building of a causeway and an increase in salinity was to blame (Pérez-Cao, 2004). The absence (Cayo Coco), or low rate (Matanzas), of resightings of photoidentified individuals was interpreted that no residency or closed communities exist. Hence PérezCao (2004) refrained from estimating absolute abundance in the study areas and further indicated (p.72) that the [relative] abundance estimates cannot be used to establish catch quotas.

\section{Live captures}

Over a 19 year period (1986-2004), a reported 238 common bottlenose dolphins have been exported from Cuba, more than $60 \%$ of these to commercial facilities in Latin America and the Caribbean, some 32\% to Europe and the rest to Canada and Israel. Growth in export numbers has been very significant (Figure 1), up to 28 individuals per annum in 2002. No information is available on the additional number of common bottlenose dolphins captured for use in Cuban dolphinaria, which may be substantial.

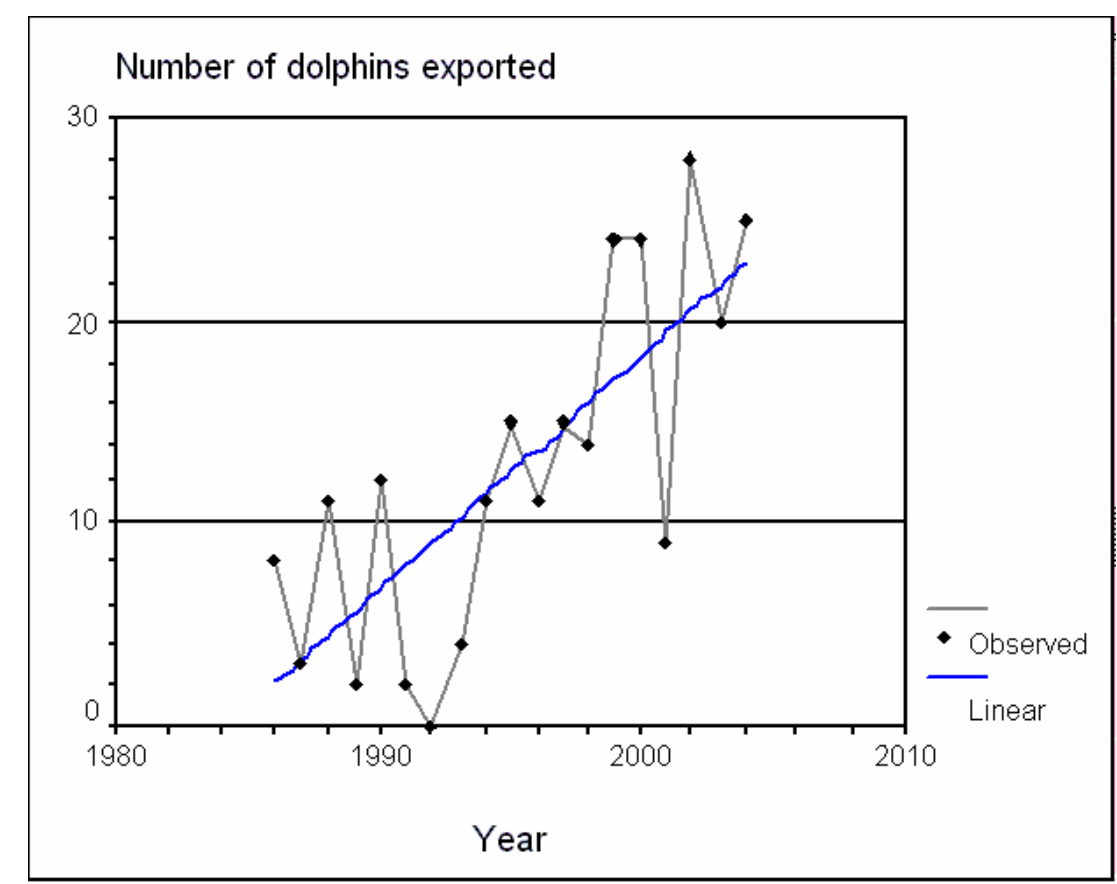

Figure 1. Linear fitting of annual live exports of common bottlenose dolphins $T$. truncatus from Cuba demonstrates a very significant, steep increase over the 19year period 1986-2004 for which data are available $\left(R^{2}=0.587 ; \mathrm{df} 1,17 ; \mathrm{F}=24.12, p\right.$ $<0.0001)$. Note that these figures are not annual catch quotas because dolphins captured for domestic dolphinaria are not included. 
While it appears unlikely that IUU (Illegal, unrecorded, unreported) live captures might occur, Cuba's EEZ waters $\left(222,204 \mathrm{~km}^{2}\right)$ amount to a very extensive area to be patrolled and some concern seems legitimate. In May 2003, five common bottlenose dolphins were illegally live captured (four died) by foreign nationals in Senegal's Siné-Saloum National Marine Park and Biosphere Reserve, confirming the brazenness of illicit dolphin traders (Van Waerebeek et al., 2003). Recently, in the Caribbean region, irregular or controversial live captures of T. truncatus were reported from Guyana (10-14 individuals) and Haiti (8 ind.) in 2004 (Fisher and Reeves, 2005; IWC, 2006) and the Dominican Republic (2 and 8 dolphins in 1995 and 2000 respectively) (E.C.M. Parsons et al., 2006) ${ }^{12}$. In March 2005, 15 bottlenose dolphins (9 females and 6 males) were live-captured near Roatan Island, Honduras, to stock a local sea pen facility (M. Iñiguez, pers. communication in IWC, 2006).

Bottlenose dolphins in inshore or coastal habitat typically form smaller groups than in offshore waters (e.g. Shane et al., 1986; Wells and Scott 1999; K.Van Waerebeek, unpublished data). With inshore animals easily accessible for shallow water seine-netting expeditions, the live display industry preferentially exploits such populations. Group size data also suggest that the Cuban dolphin harvest exploits one or more inshore stocks. Anon. (2003) cited a mean group size of 8.3 ind./group off Matanzas and 4.0 ind./group off Cayo Coco, broadly comparable with other coastal areas in the region. For instance, off Puerto Rico and the Virgin Islands, group sizes averaged 5.5-8.4 (Mignucci-Giannoni, 1998) and 9.0 animals respectively (Roden and Mullin, 2000). Lowest values were found in Belize, where they ranged 2.9-3.8 in shallow water around two offshore atolls (Campbell et al., 2002; Kerr et al., 2005).

Inshore (coastal) T. truncatus are especially vulnerable to hunting, incidental catch, and habitat degradation (Curry and Smith, 1997), due to their physical proximity to people and because population abundance is typically low, e.g. 'less than 60 individuals' off NE Margarita Island, Venezuela (Oviedo and Silva, 2005) and an estimated 122 in the Drowned Cayes, Belize (Kerr et al., 2005). Off northcentral Chile, a single pod of about 30 animals seemed to constitute a management unit (Sanino et al., 2005).

Anon. (2003, p.11) refers to a morphometric study (14 measurements) based on 223 specimens, 89 of these males $^{13}$, from three localities in Cuba, almost certainly the results from Blanco ${ }^{14}$ and Olachea (2002; not seen). Presumably these comprise external measurements of livecaptured animals and perhaps a few complete, fairly fresh stranded carcases (but no by-caught ones, see below) in which case all or nearly all specimens must have been sexed. If so, this substantial sample suggests high levels of captured or dead common bottlenose dolphins, with a significant sex bias towards females (0.60; binomial test, two-sided $p=0.0028$ ). A preference for young females is a regular feature in the global trade of live cetaceans.

\section{Bycatches}

In 2003, the Cuban CITES administrative authority indicated ${ }^{15}$ that the illegal capture and bycatch of $T$. truncatus is practically zero because there is no tradition of [dolphin meat] consumption in Cuba and no conflict exists with fisheries in areas where this species occurs. However, it is unclear whether this statement is based on independent observational data, or rather on a lack of bycatch reports from fishermen and other fisheries' stakeholders. Self-reporting is known to be very unreliable. There are no indications of an operational observer scheme (sensu Northridge, 1996) tasked with the monitoring and reporting of cetacean bycatches in Cuba's EEZ. In fact, on a global scale, few countries have any effective reporting system for bycatch of any species (Read et al., 2006). Bycatches and other lethal takes of small cetaceans are notoriously difficult to detect, particularly if illegal. At sea, carcases are either discarded or utilized onboard as bait, or alternatively, may be clandestinely landed for food (e.g. Northridge, 1984; IWC, 1994; Van Waerebeek and Reyes, 1994).

In 1995 , about $38.9 \%$ of Cuban marine fisheries resources were in a senescent phase, $48.7 \%$ were in a mature phase at a high exploitation level and only $12.4 \%$ were still in a developing phase; none of the fisheries remained undeveloped (Baisre, 2000). Similarly, Claro et al. (2001) indicated that the majority of fisheries resources in Cuban waters are considered fully or over-exploited. Price pressures on fuel intensive offshore fisheries, essentially shutting down the longdistance fleets, led to a major restructuring of the fishing industry in Cuba in the 1990s (Adams et al., 2000).

\footnotetext{
${ }^{12}$ Parsons, E. C. M., Bonnelly De Calventi, I., Whaley, A., Rose, N. A. and Sherwin, S. (2006) A note on illegal captures of wild bottlenose dolphins (Tursiops truncatus) from the coastal waters of the Dominican Republic. Paper SC/58/SM11 submitted to 58 ${ }^{\text {th }}$ IWC Annual Meeting, St Kitts and Nevis, May-June 2006.

${ }^{13}$ (p.11). “Se llevó a cabo el estudio morfométrico de la especie basándose en el análisis de 223 ejemplares, de ellos 89 machos. En éste se abarcaron tres localidades, identificándose la masa animales en cada una de ellas. Se tomaron como matriz 14 medidas y se analizaron los resultados con diferentes estadígrafos lográndose comparaciones entre las mismas y en su composición por sexos."

${ }^{14}$ Blanco, M. and Olachea, A. (2002) Morfometría del delfín nariz de botella (Tursiops truncatus), en la costa norte de la zona central de Cuba. XVIII Congreso Panamericano de Ciencias Veterinarias. Memorias. CD-ROM ISBN 959-7164-32-9 [not seen].

15 In litteris, 24 November 2003: “... y que la captura ilegal o incidental de esta especie en Cuba es prácticamente nula pues no existe tradición de consumo de su carne y no existe conflicto entre las zonas y artes de pesca con Tursiops truncatus." [Dra. Silvia Alvarez Rossell, Director of the Administrative Authority of CITES-Cuba, to Carmen Timermans, General Director of the Administrative Authority of CITES-Spain, on Export Permit No. C0000140].
} 
Emphasis shifted from high-volume, but low-value pelagic fisheries to high-value, coastal fin- and shellfish species caught primarily in nearshore waters (Adams et al., 2000). A wide variety of species are being targeted by a wide range of gears (Baisre et al., 2003). Where areas utilized by fisheries overlap with habitat of inshore T. truncatus, as in Cuba, some level of fishery-caused mortality is to be expected. Bycatches and some direct takes of T. truncatus have long been known to occur in the Caribbean and the contiguous western central Atlantic, mostly in gillnets but also in beach seine nets (Caldwell et al., 1971; Caldwell and Caldwell, 1971; Price, 1985; Casinos, 1986; Van Waerebeek, 1990; Vidal, 1990; Vidal et al., 1994; Romero et al., 1997, 2001; O.Vasquez in IWC, 2006) as well as in much of their global range (e.g. Northridge, 1984; IWC, 1994). The fact that fisheries-caused mortality of common bottlenose dolphins occurs even in such highly regulated and monitored waters as these of the USA and western Europe (e.g. Couperus, 1997; Burdett and McFee, 2004) is indicative that some level of bycatch is unavoidable wherever fisheries operate. Northridge (1984), in recognition of this, concluded for the western central Atlantic: 'there are probably more interactions between this species [T. truncatus] and fishermen which are not recorded'.

\section{Conclusions}

We were unable to locate evidence to confirm two proposed hypotheses: (1) T. truncatus off SabanaCamagüey, northern Cuba, not showing any population structure, and (2) virtually no bycatches of this species occur in Cuban waters. On the other hand, analysis of the WCMC data demonstrated a very significant increase in numbers of common bottlenose dolphins caught and exported from Cuba.

From analogies with global fisheries, we deduct that some level of dolphin bycatch mortality in Cuba's fully developed marine fisheries is likely. Well-designed observer programmes on fishing vessels can yield useful bycatch estimates of small cetaceans per unit of effort (e.g. Couperus, 1997; Zeeberg et al., 2006) but assessments should be regularly updated. Other potential threats, including coastal habitat encroachment such as aquaculture development (Watson-Capps and Mann, 2005), pollution (e.g. Schwacke et al., 2002), propeller strikes and reduced prey supplies, considering $87.9 \%$ of Cuba's marine fishery resources are in a critical stage (Baisre, 2000), also ought to be evaluated. Such anthropogenic pressures may result in reduced foraging success, increased morbidity and diminish normal recruitment rates within the population(s), ultimately leading to a lesser capacity to cope with direct removals. The IWC Scientific Committee's Subcommittee on Small Cetaceans also concluded that habitat degradation and pollution were potential conservation issues in the Caribbean and the western tropical Atlantic; and that there was insufficient information to assess the status of common bottlenose dolphins in the region (IWC, 2006).

As discussed above, with advancing phylogenetics research of T. truncatus, globally, the trend is discovery of unexpected, and considerably more complex, stock structure, strengthening the argument for higher precaution until ongoing research ( $c f$. Anon., 2003) is completed and published.

We conclude that the available documentation is not sufficient for the international community of marine mammal scientists to assess the sustainability of current capture levels of Tursiops truncatus in Cuban waters. Therefore, we strongly recommend that international trade of common bottlenose dolphins from this area ceases until evidence of no detriment can be authenticated. Continued field research on stock structure, abundance, life history, habitat degradation and anthropogenic threats is also greatly encouraged (cf. Reeves et al., 2003; IWC, 2006).

\section{Acknowledgements}

Reviewers Dr. Randall Reeves and Dr. Randall Wells are thanked for providing detailed comments that significantly improved the paper. Randall Wells also kindly provided a copy of Mrs. Pérez-Cao's dissertation.

\section{References}

Adams, C., Sanchez-Viga, P. and Garcia-Alvarez, A. (2000) An overview of the Cuban commercial fishing industry and recent changes in management structure and objectives. Institute of Food and Agricultural Sciences, University of Florida, Gainsville, EDIS document FE 218. 8pp.

Aguayo, C.G. (1954) Notas sobre cetáceos de aguas Cubanas. Circulares del Museo y Biblioteca de Zoologia de La Habana 13(351): 1125-1126.

ANONYMUs (2003) Informe general acerca de los trabajos de investigación y desarrollo sobre el delfín tonina Tursiops truncatus (Montagu, 1821) en Cuba. Scientific Review Group, SRG 28, Inf 7. 15pp. Unpublished. [in Spanish].

BAISRE, J.A. (2000) Chronicle of Cuban marine fisheries (19351995): trend analysis and fisheries potential. FAO Fisheries Technical Paper 394. 34pp.

Baisre, J., Booth, S. And Zeller, D. (2003) Cuban fisheries catches within FAO area 31 (Western Central Atlantic): 19501999. Fisheries Centre Research Reports 11(6): 133-139.

Blaylock, R.A., Hain, J.W., Hansen, L.J., Palka, D.L. And WARING, G.T. (1995) US Atlantic and Gulf of Mexico marine mammal stock assessments. NOAA Technical Memorandum NMFS-SEFSC-363. 211pp.

Burdett, L.G. AND McFEe, W.E. (2004) Bycatch of bottlenose dolphins in South Carolina, USA, and an evaluation of the Atlantic blue crab fishery categorisation. Journal of Cetacean Research and Management 6(3): 231-240. 
Caldwell, D.C. and Caldwell, M.C. (1971) Porpoise fisheries in the southern Caribbean - present utilization and future potentials. Proceedings of the Gulf and Caribbean Fisheries Institute 32(7): 195-206.

Caldwell, D.C., Caldwell, M.C., Rathjen, W.F. and Sullivan, J.R. (1971) Cetaceans from the lesser Antillean island of St.Vincent. Fishery Bulletin 69(2): 303-312.

Campbell, G.S., Bilgre, B.A. and Defran, R.H. (2002) Bottlenose dolphins in Turneffe Atoll, Belize: occurrence, site fidelity, group size, and abundance. Aquatic Mammals 28: 170-180.

CAsinos, A. (1986) La fauna de cetáceos del Caribe Sudoriental. Pages 42-55 in Castello, H.P. (Ed.) Actas de la Primera Reunión de Trabajo de Expertos en Mamíferos Acuaticos de America del Sur. Fundación Vida Silvestre Argentina, Buenos Aires, Argentina. [in Spanish].

Caughley, G. (1977) Analysis of vertebrate populations. New York: Wiley.

Claro, R., Baisre, J.A., Lindeman, K.C. and García-Arteaga, J.P. (2001) Cuban Fisheries: Historical Trends and Current Status. Pages 194-219 in Claro, R., Lindeman, K.C. And Parenti, L.R. (Eds) Ecology of the Marine Fishes of Cuba. Smithsonian Institution Press, Washington.

Corkeron, P. (2002) Captivity. Pages 192-197 in Perrin, W.F., WÜrsig B. AND Thewissen J.G.M. (Eds) Encyclopedia of Marine Mammals. Academic Press.

Couperus, A.S. (1997) Interactions between Dutch Midwater Trawl and Atlantic white-sided dolphins (Lagenorhynchus acutus) Southwest of Ireland. Journal of Northwest Atlantic Fisheries Science 22: 209-218.

CuRrY, B.E. AND SMItH, J. (1997) Phylogeographic structure of the bottlenose dolphin (Tursiops truncatus): stock identification and implications for management. Pages 227-247 in Dizon, A.E., Chivers, S.J. ANd PerRIN W.F. (Eds) Molecular Genetics of Marine Mammals. Society for Marine Mammalogy, Special Publication 3, Allen Press, Lawrence, Kansas.

Debrot, A.O., De Meyer, J.A. and Dezentjé, P.J.E. (1998) Additional records and a review of the cetacean fauna of the Leeward Dutch Antilles. Caribbean Journal of Science 34 (3-4): 204-210.

Duffield, D.A. And Wells, R.S. (1991) The combined application of chromosome, protein and molecular data for the investigation of social unit structure and dynamics in Tursiops truncatus. Pages 155-169 in Hoelzel, A.R. (Ed.) Genetic Ecology of Whales and Dolphins.

Erdman, D.S. (1970) Marine mammals from Puerto Rico to Antigua. Journal of Mammalogy 51(3): 636-639.

ERDMAn, D.S., Harms, J. AND Flores, M.M. (1973) Cetacean records from the northeastern Caribbean region. Cetology 17: 1-14.

Fisher, S.J. AND REEves, R.R. (2005) The global trade in live cetaceans: implications for conservation. Journal of International Wildlife Law and Policy 8: 315-340.

Hersh, S.L. AND Duffield, D.A. (1990). Distinction between Northwest Atlantic offshore and coastal bottlenose dolphins based on hemoglobin profile and morphometry. Pages 129139 in Leatherwood, S. and Reeves, R.R. (Eds) The Bottlenose Dolphin. Academic Press, San Diego.

Hoelzel, A.R., Potter, C.W. and Best, P. (1998) Genetic differentiation between parapatric 'nearshore' and 'offshore' populations of the bottlenose dolphin. Proceedings of the Royal Society of London B 265: 1-7.

IWC (1994) Gillnets and cetaceans. Pages 1-629 in PERRIN, W.F., DONOVAN G.P. AND BARLOW J. (Eds) Report of the International Whaling Commission (special issue 15).

IWC (2006). Report of the Scientific Committee, Annex L, Report of the Sub-Committee on small cetaceans. International Whaling Commission, St. Kitts and Nevis, June 2006.

Irvine, A.B., Scott, M.D.,Wells, R.S. and Kaufmann, J.H. (1981) Movements and activities of the Atlantic bottlenose dolphin, Tursiops truncatus, near Sarasota, Florida. Fishery Bulletin of the U.S. 79: 671-688.

JEFFERSON, T.A. AND LYNN, S.K. (1994) Marine mammal sightings in the Caribbean Sea and Gulf of Mexico, summer 1991. Caribbean Journal of Science. 30(1-2): 83-89.

Kerr, K.A., Defran, R.H. and Campbell, G.S. (2005) Bottlenose dolphins (Tursiops truncatus) in the Drowned Cayes, Belize: group size, site fidelity and adundance. Caribbean Journal of Science 41(1): 172-177.

LeDuc, R. G. and Curry, B. E. (1997) Mitochondrial DNA sequence analysis indicates need for revision of the genus Tursiops. Report of the International Whaling Commission 47: 393.

Macleod, C.D., Hauser, N. And PecKham, H. (2004) Diversity, relative density and structure of the cetacean community in summer months east of Great Abaco, Bahamas. Journal of the Marine Biological Association UK 84: 469-474.

McLellan, W.A., Friedlaender, A.S., Mead, J.G., Potter, C.W. AND PABST, D.A. (2002) Analysing 25 years of bottlenose dolphin (Tursiops truncatus) strandings along the Atlantic coast of the USA: do historical records support the coastal migratory stock hypothesis? Journal of Cetacean Research and Management 4(3): 297-304.

McLoughlin, P.D., Taylor, M.K. and Messier, F. (2005) Conservation risks of male-selective harvest for mammals with low reproductive potential. Journal of Wildlife Management 69(4): 1592-1600.

Mead, J.G. and Potter, C.W. (1995) Recognizing two populations of the bottlenose dolphin (Tursiops truncatus) off the Atlantic coast of North America: morphologic and ecologic considerations. IBI Reports (International Marine Biological Research Institute, Kamogawa, Japan) 5: 31-44.

MignucCi-Giannoni, A.A. (1998) Zoogeography of cetaceans of cetaceans off Puerto Rico and the Virgin Islands. Caribbean Journal of Science 34 (3-4): 173-190.

Mignucci-Giannoni, A.A., Pinto-Rodríguez, B., VelascoEscudero, M., Montoya-Espina, R.A., JimÉnez-Marrero, N.M., Rodríguez-López, M.A., Williams JR., E.H. ANd Odell, D.K. (1999) Cetacean strandings in Puerto Rico and the Virgin Islands. Journal of Cetacean Research and Management 1(2): 191-198.

Northridge, S.P. (1984) World review of interactions between marine mammals and fisheries. FAO Fisheries Technical Paper 251. 190pp.

NorTHRidGE, S.P. (1996) A review of marine mammal bycatch observer schemes with recommendations for best practice. JNCC report 219. Joint Nature Conservation Committee, Aberdeen, United Kingdom. 
Oviedo, L. AND SILVA, N. (2005) Sighting frequency and relative abundance of bottlenose dolphins (Tursiops truncatus) along the northeast coast of Margarita Island and Los Frailes Archipelago, Venezuela. International Journal of Tropical Biology 53 (595-600).

Parsons, K.M., Durban, J.W., Claridge, D.E., Herzing, D.L., Balcomb, K.C. and Noble, L.R. (2006) Population genetic structure of coastal bottlenose dolphins (Tursiops truncatus) in the northern Bahamas. Marine Mammal Science 22(2): 276-298.

Pérez-CAO, H. (2004) Abundancia y distribución de la tonina Tursiops truncatus (Montagu, 1821) en dos areas del Archipiélago Sabana-Camagüey, Cuba. Tesis presentada en opción al Título Académico de Master en Biología Marina y Acuicultura con mención en Biología Marina. Universidad de La Habana, Cuba. 86pp.

PRICE, W.S. (1985) Whaling in the Caribbean: historical perspective and update. Report of the International Whaling Commission 35: 413-420.

Read, A.J., Drinker, P. And Northridge, S. (2006) Bycatch of marine mammals in U.S. and global fisheries. Conservation Biology 20(1): 163-169.

Reeves, R.R., Smith, B.D., Crespo, E.A. and Notarbartolo di Sciara, G. (compilers) (2003) Dolphins, Whales and Porpoises: 2002-2010 Conservation Action Plan for the World's Cetaceans. IUCN/SSC Cetacean Specialist Group. IUCN, Gland, Switzerland and Cambridge, UK. xi + 139pp.

Rendell, L. AND Whitehead, H. (2001) Culture in whales and dolphins. Behavioral and Brain Sciences 24 (2001): 309-382.

Rice, D.W. (1998) Marine mammals of the world: systematics and distribution. The Society for Marine Mammalogy, Special publication 4, Allen Press, Lawrence, KS, 231pp.

Roden, C.L. And Mullin, K.D. (2000) Sightings of cetaceans in the northern Caribbean Sea and adjacent waters, winter 1995. Caribbean Journal of Science 36 (3-4): 280-288.

Romero, A., Agudo, A.I. AND GreEn, S.M. (1997) Exploitation of cetaceans in Venezuela. Report of the International Whaling Commission 47: 735-746.

Romero, A., Agudo, A.I., Green, S.M. and Notabartolo Di Sciara, G. (2001) Cetaceans of Venezuela: their distribution and conservation status. NOAA Technical Report NMFS 151. 60pp.

Sanino, G.P., Van Waerebeek, K., Van Bressem, M.-F. and Pastene, L.A. (2005) Preliminary mitochondrial DNA analysis on population structure in eastern South Pacific common bottlenose dolphins, Tursiops truncatus. Journal of Cetacean Research and Management 7(1): 65-70.

SchmidLy, D.J. (1981) Marine mammals of the southeastern United States coast and the Gulf of Mexico. US Fish Wildife Service FWS/OBS-80/41. 165pp.

SchWAcKe, L.H., Voit, E.O., Hansen, L.J., Wells, R.S., Mitchum, G.B., HoHn, A.A. AND FAIR, P.A. (2002). Probabilistic risk assessment of reproductive effects of polychlorinated biphenyls on bottlenose dolphins (Tursiops truncatus) from the Southeast United States Coast. Environmental Toxicology and Chemistry 21(12): 2752-2764.

Scott, M.D., Wells, R.S. And Irvine, A.B. (1990) A long-term study of bottlenose dolphins on the west coast of Florida. Pages 235-244 in Leatherwood, S. and Reeves, R.R. (Eds). The Bottlenose Dolphin. Academic Press, San Diego.
Sellas, A.B., Wells, R.S. and Rosel, P.E. (2005) Mitochondrial and nuclear DNA analyses reveal fine scale geographic structure in bottlenose dolphins (Tursiops truncatus) in the Gulf of Mexico. Conservation Genetics 6: 715-728.

Shane, S.H., Wells, R.S. And WÜrsig, B. (1986) Ecology, behavior and social organization of bottlenose dolphins: a review. Marine Mammal Science 2(1): 34-63.

SNYder, N.F.R., Derrickson, S.R., Beissinger, S.R., Wiley, J.W., Smith, T.B., Toone, W.D. AND Miller, B. (1996) Limitations of captive breeding in endangered species recovery. Conservation Biology 10(2): 338-348.

Van Waerebeek, K. (1990) Preliminary notes on the existence of a dolphin by-catch off French Guiana. Aquatic Mammals 16(2): 71-72.

Van Waerebeek, K., Reyes, J.C., Read, A.J. and Mckinnon, J.S. (1990) Preliminary observations of bottlenose dolphins from the Pacific coast of South America. Pages 143-154 in Leatherwood, S. AND Reeves, R.R. (Eds) The Bottlenose Dolphin. Academic Press, San Diego, CA.

Van Waerebeek, K. and Reyes, J.C. (1994) Post-ban small cetacean takes off Peru: a review. Reports of the International Whaling Commission (special issue 15): 503-520.

Van Waerebeek, K., Barnett, L., Camara, A., Cham, A., Diallo, M., Ditba, A., Jallow, A.O., Ndiaye, E., Samba Ould Bilal, A.O. AND BAMY, I.L. (2003) Conservation of cetaceans in The Gambia and Senegal 1999-2001, and status of the Atlantic humpback dolphin. WAFCET-2 Report. UNEP/CMS, Bonn, Germany. 55pp.

VIDAL, O. (1990) Lista de los mamíferos acuáticos de Colombia. Informe del Museo del Mar (Bogotá) 37: 1-18.

Vidal, O., VAN WAEREBEeK, K. AND FindLEY, L.T. (1994) Cetaceans and gillnet fisheries in Mexico, Central America and the Wider Caribbean: a preliminary review. Reports of the International Whaling Commission (special issue 15): 221-233.

WANG, J.Y., Chou, L.-S. AND White, B.D. (1999) Mitochondrial DNA analysis of sympatric morphotypes of bottlenose dolphins (genus: Tursiops) in Chinese waters. Molecular Ecology 8: 1603-1612.

Waring, G.T., Josephson, E., Fairfield, C.P. And MaZe-Foley, K. (Editors) (2005) U.S. Atlantic and Gulf of Mexico Marine Mammal Stock Assessments 2005. NOAA Technical Memorandum NMFS-NE-194. 358pp.

WATSON-CAPPS, J.J. AND MANN, J. (2005) The effects of aquaculture on bottlenose dolphin (Tursiops sp.) ranging in Shark Bay, Western Australia. Biological Conservation 124: 519-526.

Wells, R.S. (1991) The role of long-term study in understanding the social structure of a bottlenose dolphin community. Pages 199-225 in: PrYOR, K. AND NorrIs, K.S. (Eds.) Dolphin Societies: Discoveries and Puzzles. University of California Press, Berkeley. 397 pp.

Wells, R.S. And Scott, M.D. (1999) Bottlenose dolphin Tursiops truncatus (Montagu, 1821). Pages 137-182 in RIDGWAY, S.H. AND Harrison, R. (Eds) Handbook of Marine Mammals. Volume 6: The Second Book of Dolphins and the Porpoises. Academic Press, San Diego.

WeLls, R.S., ScotT, M.D. AND IRVINE, A.B. (1987) The social structure of free-ranging bottlenose dolphins. Pages 247-305 in GeNOWAYS, H. (Ed.) Current Mammalogy, Vol. 1. New York: Plenum Press. 
WeLLS, R.S. (2003) Dolphin social complexity: Lessons from long-term study and life history. Pages 32-56 in DE WAAL, F.B.M. And Tyack, P.L (Eds) Animal Social Complexity: Intelligence, Culture, and Individualized Societies. Harvard University Press, Cambridge, MA.

Wells, R.S. AND ScotT, M.D. (2004) Bottlenose dolphin Tursiops truncatus and T. aduncus. Pages 122-127 in PerRIN, W.F., WÜRSIG, B. AND Thewissen, J.G.M. (Eds) Encyclopedia of Marine Mammals. Academic Press.

Zeeberg, J., Corten, A. And de GraAf, E. (2006) Bycatch and release of pelagic megafauna in industrial trawler fisheries off Northwest Africa. Fisheries Research 78: 186-195. 